\title{
Activity patterns, diet, and feeding efficiency of Harlequin Ducks breeding in northern Labrador
}

\author{
Michael S. Rodway
}

\begin{abstract}
The lack of data on summer diet and feeding behaviour for the endangered eastern North American population of Harlequin Ducks (Histrionicus histrionicus) prompted a study of activity patterns and feeding ecology in a coastal stream in Hebron Fiord, Labrador. Diurnal activity patterns varied by habitat and changed through the season. Extensive feeding occurred in slow-moving waters, contrary to expectation. Females spent $40 \%$ of daylight hours feeding during the prelaying period, more than twice the time spent by males and higher than that reported in other studies. Diurnal feeding patterns showed little variation in the prelaying period and major peaks of activity in the morning and evening during incubation and brood rearing. Larval Simuliidae (Diptera) were absent from a fecal sample taken in July but dominated the prey remains in feces collected in August. Dive times averaged 10-24 s and varied with depth of water. Dive-pause ratios of 1.7-2.2 were lower than previously reported. The results support the hypothesis that populations are food-limited on the breeding grounds, and suggest that there may be greater energy constraints on foraging effort in river specialists than in dabbling or other diving waterfowl.
\end{abstract}

Résumé : La rareté des données sur le régime et le comportement alimentaires d'été chez la population menacée de l'Arlequin plongeur (Histrionicus histrionicus) de l'est nord-américain a donné lieu à une étude de l'activité et de l'écologie alimentaires dans un ruisseau côtier du fjord d'Hebron, Labrador. L'activité diurne variait en fonction de l'habitat et a fluctué durant toute la saison. Étonnamment, les canards se sont alimentés abondamment dans les eaux lentes. Les femelles ont passé $40 \%$ des heures d'éclairement à se nourrir avant la période de pré-ponte, plus de deux fois plus longtemps que les mâles et plus longtemps que la durée signalée dans les autres études. L'alimentation pendant la journée subissait peu de variations au cours de la période de pré-ponte et deux périodes principales d'activité alimentaire ont été observées, le matin et le soir, durant l'incubation et l'élevage des couvées. Les larves de diptères simuliidés se sont avérées absentes d'un échantillon de fèces prélevé en juillet, mais constituaient les proies principales dans les fèces récoltées en août. La durée des plongées variait de 10 à $24 \mathrm{~s}$ en moyenne selon la profondeur de l'eau. Les rapports plongée-pause évalués à 1,7-2,2 ont été inférieurs aux valeurs mesurées au cours d'études précédentes. Les résultats appuient l'hypothèse selon laquelle les populations sont régies par la nourriture sur les territoires de reproduction et indiquent qu'il peut s'exercer sur l'effort de quête de nourriture des contraintes énergétiques plus importantes chez les spécialistes des eaux courantes que chez les canards barboteurs ou chez les autres oiseaux plongeurs. [Traduit par la Rédaction]

\section{Introduction}

Harlequin Ducks (Histrionicus histrionicus) nest primarily on swift-flowing streams (Bengtson 1966, 1972; Kuchel 1977; Dzinbal 1982; Wallen 1987; Inglis et al. 1989; Cassirer and Groves 1991; Rodway et al. 1998), where they feed on benthic invertebrates by diving, skimming, and upending (Bengtson 1966, 1972). A few studies of feeding ecology have been conducted in Iceland (Bengtson 1966, 1972; Bengtson and Ulfstrand 1971; Inglis et al. 1989), Montana (Wallen 1987), and Alaska (Dzinbal 1982; Dzinbal and Jarvis 1984).

The breeding ecology of the endangered eastern North American population of Harlequin Ducks (Goudie 1991) is poorly known and data on summer diet and feeding behaviour

Received April 15, 1997. Accepted January 12, 1998.

M.S. Rodway ${ }^{1}$ Department of Biology, Memorial University of Newfoundland, St. John's, NF A1B 3X9, Canada.

1 Present address: Department of Biological Sciences, Simon Fraser University, Burnaby, BC V5A 1S6, Canada (e-mail: msrodway@sfu.ca). for this population are lacking. Food availability on the breeding grounds may limit populations (Bengtson and Ulfstrand 1971; Bengtson 1972), and greater understanding of food requirements and activity budgets is vital to recovery plans (Montevecchi et al. 1995). I investigated the feeding ecology of Harlequin Ducks on a coastal stream in northern Labrador, an area thought to support a substantial proportion of the eastern North American breeding population (Goudie 1991). The objectives of the study were to $(i)$ determine activity patterns through a breeding season, especially the proportion of time spent foraging; (ii) relate foraging effort to reproductive status and sex; (iii) measure dive-pause ratios to obtain an estimate of feeding efficiency; and (iv) obtain information on diet.

\section{Methods}

The study was conducted from 8 June to 14 August 1996 on an unnamed stream (Harlequin Brook; $58^{\circ} 09^{\prime} 40^{\prime \prime} \mathrm{N}, 63^{\circ} 04^{\prime} 45^{\prime \prime} \mathrm{W}$ ), a tributary of the Ikarut River in the northwestern arm of Hebron Fiord, Labrador (Fig. 1). Coastal tundra habitat in the area rises to 400-700 $\mathrm{m}$, with dense, shrub-covered sections along stream banks and on islands.

Four observation stations were established at 0 (estuary), 1.7 
Fig. 1. Locations of study site and observation stations on Harlequin Brook, Hebron Fiord, Labrador, in 1996.

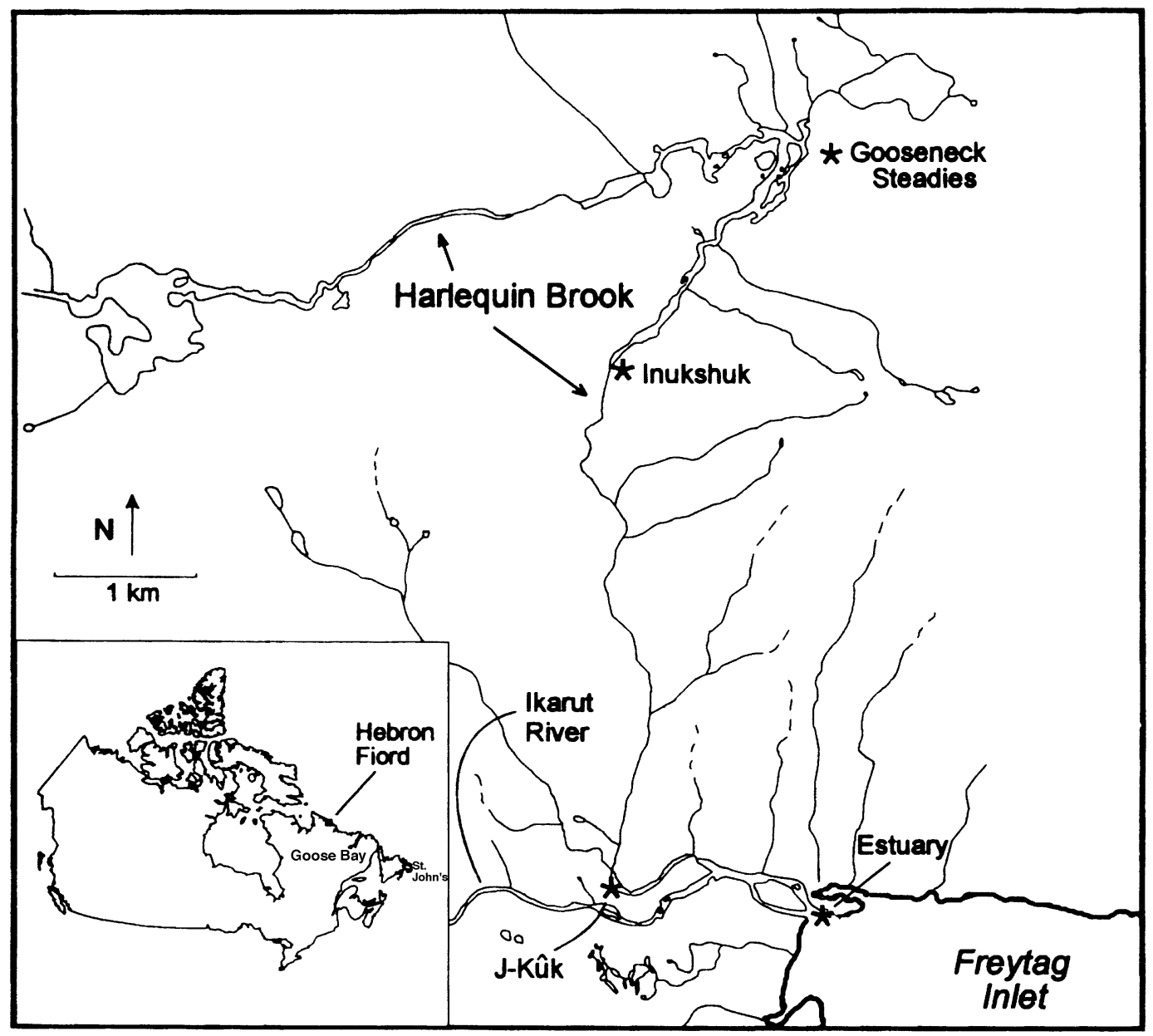

(J-Kûk), 6.0 (Inukshuk), and $8.3 \mathrm{~km}$ (Gooseneck Steadies) from the estuary at sites that were known to be frequented by Harlequin Ducks (Fig. 1). Stations were placed at vantage points above the river, except at the estuary where the station was on a broad sandbar, providing views of as much of the river as possible (about $500 \mathrm{~m}$, on average). Depth and flow rate were $1-2 \mathrm{~m}$ and $1.0 \mathrm{~m} / \mathrm{s}, 0.5-1.5 \mathrm{~m}$ and $0.6 \mathrm{~m} / \mathrm{s},<0.5 \mathrm{~m}$ and $1.8 \mathrm{~m} / \mathrm{s}$, and $0.5-2.0 \mathrm{~m}$ and $<0.2 \mathrm{~m} / \mathrm{s}$ over a substrate of pebbles, pebbles, boulders, and silt at the four stations, respectively. There was little shoreline vegetation at the estuary, sparse shrub cover at Inukshuk, and dense, overhanging shrubs at J-Kûk and Gooseneck Steadies. There were islands at Inukshuk and Gooseneck Steadies. J-Kûk was just downstream from a cluster of shrub-covered islands where Harlequin Ducks were known to nest (Rodway et al. 1998). Gooseneck Steadies is a meandering lake-like area with small, rapidly flowing feeder streams entering from the north and northwest. Ice and snow covered much of the shoreline and overhung sections of the brook at all stations during the first observation period.

Diurnal activity patterns were determined during the prelaying to early laying (16-21 June, 03:00-24:00; hereafter called prelaying), incubation (15-20 July, 04:00-23:00), and early brood-rearing periods (2-6 August, 04:30-22:30). Four-hour observation sessions were staggered over 3-4 days so that combined time blocks were representative of a full daylight period at each observation station. Additional observations were made from 02:00 to $03: 00$ and 23:00 to 23:30 on 17 June, from 03:00 to 04:00 on 16 July, and from 04:00 to 04:30 on 3-4 August to check for possible night feeding.
Behaviour was determined by means of instantaneous scansampling of focal groups at 30-s intervals (Altmann 1974). Groups of 1-4 birds (chosen or, often, the only birds present) were followed throughout the time they were visible from the observation post. Pairs were chosen during the prelaying period in order to compare male and female behaviour. Birds were considered present if they were out of sight behind islands or rocks but were known to be in the area, therefore numbers of observations do not always correspond to the percentage of time birds were present (see Tables 1 and 2). "Total number of birds $\times$ hours" is the number of birds multiplied by the length of time they were present during an observation period.

Feeding behaviours were categorized as diving, skimming, and upending (Bengtson 1972). Diving included time spent on the surface as well as under water unless the interval between dives was longer than $30 \mathrm{~s}$, which is close to the maximum recorded dive time for Harlequin Ducks (Bengtson 1966, 1972; Inglis et al. 1989; see Results). Intervals longer than $30 \mathrm{~s}$ were coded as swimming. Divepause ratios were used to calculate time spent under water to allow comparisons with other studies. Dive and pause times were determined by recording to the nearest second when birds dove and resurfaced. Skimming refers to picking drifting prey from off or just under the surface or from stream banks, as well as scraping prey off shallow rocks without submerging. Putting the head under water and peering towards the bottom ("looking") and swimming were not considered feeding behaviours. Other behaviours are described in Bengtson (1966) and Inglis et al. (1989), using terminology from Myers (1959). 
Table 1. Relative use by Harlequin Ducks of four observation areas on Harlequin Brook, Labrador, during dawn-to-dusk observations from 03:00 to 24:00, 04:00 to 23:00, and 04:30 to 22:30 in the prelaying to early laying, incubation, and brood-rearing period, respectively, in 1966 .

\begin{tabular}{|c|c|c|c|c|}
\hline & Estuary & J-Kûk & Inkshuk & $\begin{array}{c}\text { Gooseneck } \\
\text { Steadies }\end{array}$ \\
\hline \multicolumn{5}{|c|}{ Prelaying to early laying period } \\
\hline \multicolumn{5}{|l|}{ Percentage of time present } \\
\hline Males & 5.1 & 70.3 & 4.2 & 65.0 \\
\hline Females & 5.4 & 71.9 & 4.2 & 71.9 \\
\hline \multicolumn{5}{|l|}{ No. of birds $\times$ hours } \\
\hline Males & 1.2 & 37.7 & 0.9 & 13.7 \\
\hline Females & 1.2 & 50.7 & 0.9 & 39.7 \\
\hline \multicolumn{5}{|c|}{ Incubation period (females) } \\
\hline Percentage of time present & 3.1 & 20.5 & 71.7 & 17.9 \\
\hline No. of bird $\times$ hours & 0.7 & 9.3 & 40.4 & 6.8 \\
\hline \multicolumn{5}{|c|}{ Brood-rearing period } \\
\hline \multicolumn{5}{|l|}{ Percentage of time present } \\
\hline Parent females & 0.0 & 5.6 & 47.6 & 48.0 \\
\hline Chicks & 0.0 & 5.6 & 47.6 & 48.0 \\
\hline Nonbreeding females & 6.4 & 15.0 & 97.6 & 0.0 \\
\hline \multicolumn{5}{|l|}{ No. of bird $\times$ hours } \\
\hline Parent females & 0.0 & 1.0 & 8.4 & 8.6 \\
\hline Chicks & 0.0 & 3.0 & 51.3 & 51.8 \\
\hline Nonbreeding females & 2.2 & 5.1 & 38.4 & 0.0 \\
\hline
\end{tabular}

Diet was determined from fecal samples collected on 4 August from a roosting site used for much of the previous 3 days by 4 failed or nonbreeding females at the Inukshuk observation area. An additional fecal sample collected from a mist-netted female on 3 July below the J-Kûk observation post gave an indication of diet earlier in the season. Insect parts from feces were sorted and identified to family for Diptera and to order for other taxa, using Pennak (1953) and Lehmkuhl (1979). Importance of each prey type is presented as a numerical proportion, which tends to underestimate the relative biomass of larger prey.

Non-independent, sequential observations of behaviour and dive and pause times were not appropriate for statistical analyses. As it was not possible to choose individuals randomly for observations, owing to the small numbers of birds present, I randomly picked $10 \%$ of total observations to use in statistical comparisons. Chi-squared tests were used to compare proportions of randomly chosen observations classed as feeding among groups. Dive and pause times were averaged for each diving bout by an individual, and one-way ANOVA was used to compare means of average dive and pause times among birds differing in reproductive status and sex.

\section{Results}

\section{Activity patterns}

Diurnal activity patterns varied by habitat and changed through the season. Most activity occurred at J-Kûk and Gooseneck Steadies during the prelaying period, at Inukshuk during the incubation period, and at Inukshuk and Gooseneck Steadies during the brood-rearing period (Table 1). J-Kûk was used as a loafing area by a "club" (Bengtson 1966) of up to 6 males and 10 females that spent most of their time resting and swimming. Groups of up to 5 nonbreeding or failed (hereafter, nonbreeding) females regularly roosted on the edge of the largest shrub-covered island at Inukshuk during the incubation and brood-rearing periods. Most feeding occurred at Inukshuk and Gooseneck Steadies. Little use was made of the estuary throughout the season. The main activities there were swimming and flying, birds being often in transit between the higher brook and offshore in the fiord.

Females spent more time feeding than males during the prelaying period $\left(\chi_{1}^{2}=27.4, P<0.001\right)$ and spent more time feeding in the prelaying than in the incubation $\left(\chi_{1}^{2}=71.8, P<\right.$ $0.001)$ and brood-rearing periods $\left(\chi_{1}^{2}=35.2, P<0.001\right.$; Table $2)$. Females during incubation and with accompanying broods had the lowest and similar feeding rates $\left(\chi_{1}^{2}=2.73, P=\right.$ 0.098 ) and chicks the highest (though not significantly higher than prelaying females; $\left.\chi_{1}^{2}=1.18, P=0.227\right)$. Females without broods spent more time feeding than those with broods $\left(\chi_{1}^{2}=10.34, P=0.001\right)$. Aggressive and courtship behaviours occurred primarily during the prelaying period (Table 2). Aggressive encounters were observed during the brood-rearing period as females attending broods chased off closely approaching nonbreeding females. Alert behaviour by females was most frequent during the brood-rearing period.

Diurnal feeding patterns also changed through the season. Males and females in the prelaying period fed through most daylight hours, with no obvious peaks (Fig. 2). Females during the incubation period and females with broods fed mostly in the morning and evening. Nonbreeding females fed more through the middle of the day during the brood-rearing period (Fig. 2). Birds were not seen feeding when it was dark at the beginning or end of diurnal observation periods, and no evidence of feeding was observed during nocturnal observations. Harlequin Ducks were sighted flying and swimming by the 
Table 2. Comparison of time budgets of Harlequin Ducks in the prelaying to early laying, incubation, and broodrearing periods on Harlequin Brook, Labrador, in 1996.

\begin{tabular}{|c|c|c|c|c|c|c|}
\hline & \multirow{2}{*}{\multicolumn{2}{|c|}{ Prelaying period }} & \multirow{3}{*}{$\begin{array}{c}\begin{array}{c}\text { Incubation } \\
\text { period }\end{array} \\
\text { Females }\end{array}$} & \multicolumn{3}{|c|}{ Brood-rearing period } \\
\hline & & & & \multirow{2}{*}{$\begin{array}{c}\text { Parent } \\
\text { females }\end{array}$} & \multirow[b]{2}{*}{ Chicks } & \multirow{2}{*}{$\begin{array}{c}\text { Nonbreeding } \\
\text { females }\end{array}$} \\
\hline & Males & Females & & & & \\
\hline No. of observations & 2857 & 2973 & 2172 & 1235 & 6588 & 1647 \\
\hline \multicolumn{7}{|c|}{ Percentage of total activity } \\
\hline \multicolumn{7}{|c|}{ Feeding } \\
\hline Diving & 14.3 & 32.3 & 15.6 & 8.8 & 22.9 & 21.8 \\
\hline Skimming & 2.2 & 7.3 & 1.3 & 7.3 & 21.5 & 3.6 \\
\hline Upending & 0 & $<0.1$ & 0.1 & 0 & 0.1 & 0 \\
\hline Total & 16.5 & 39.6 & 17.0 & 16.1 & 44.5 & 25.4 \\
\hline \multicolumn{7}{|l|}{ Locomotion } \\
\hline Looking & 0.8 & 0.1 & 0.5 & 0.2 & 0 & 0.2 \\
\hline Swimming & 28.9 & 18.6 & 24.3 & 34.0 & 18.6 & 21.9 \\
\hline Running & 0 & 0 & 0 & 0.2 & 0.4 & 0 \\
\hline Walking & 0.4 & 0.3 & 0 & 0.1 & 1.5 & $<0.1$ \\
\hline Flying & 0.8 & 0.5 & 1.0 & 0 & 0 & 0.1 \\
\hline Total & 30.9 & 19.5 & 25.8 & 34.5 & 20.5 & 22.2 \\
\hline \multicolumn{7}{|l|}{ Social interaction } \\
\hline Chasing & 0.5 & $<0.1$ & 0 & 0.1 & 0 & 0 \\
\hline Fleeing & 0 & 0.2 & 0 & 0 & 0 & $<0.1$ \\
\hline Head-nodding & 2.3 & 1.5 & 0.8 & 0 & 0 & 0.1 \\
\hline Total & 2.8 & 1.7 & 0.8 & 0.1 & 0 & 0.1 \\
\hline \multicolumn{7}{|l|}{ Maintainance } \\
\hline Alert & 0.6 & 0.2 & 4.0 & 9.9 & 0 & 1.0 \\
\hline Preening & 4.6 & 4.6 & 0.8 & 3.0 & 2.7 & 4.2 \\
\hline Resting & 44.6 & 34.4 & 51.7 & 36.4 & 32.4 & 47.1 \\
\hline Total & 49.8 & 39.2 & 56.5 & 49.3 & 35.1 & 52.3 \\
\hline
\end{tabular}

Note: Data are weighted by the number of birds and the percentage of time they were present at each of the four stations in order to calculate overall percentages (see Table 1).

estuary and J-Kûk observation posts at 02:00 on 17 June and 03:20 on 17 July.

\section{Feeding efficiency}

Most diving was observed at Gooseneck Steadies during the prelaying period and at Inukshuk during the incubation period. Samples of dive times from paired males and females and from unpaired females at Gooseneck Steadies during the prelaying period (Table 3 ) showed significant differences in dive times $\left(F_{[2,114]}=4.55, P=0.013\right)$ and pause times $\left(F_{[2,85]}=3.73, P=0.028\right)$, but not in dive-pause ratios $\left(F_{[2,85]}=0.90, P=0.410\right)$. Unpaired females made longer dives than paired females (Tukey's test, $P=0.009$ ) or paired males $(P=0.041)$, and took longer pauses than paired females $(P=0.041)$ but not paired males $(P=$ 0.634 )

In the shallower water at Inukshuk, dives of females were shorter $\left(F_{[2,96]}=20.6, P<0.001\right)$ during the incubation period than, and dive-pause ratios were similar to $\left(F_{[2,68]}=\right.$ $0.28, P=0.757)$, all those recorded at Gooseneck Steadies during the prelaying period and at J-Kûk during the broodrearing period (Tukey's test, $P_{\mathrm{s}}<0.001$; Table 3, Fig. 3). Maximum dive times were 35, 21, and $34 \mathrm{~s}$ at Gooseneck Steadies, Inukshuk, and J-Kûk, respectively.

\section{Diet}

Simuliidae constituted $98 \%$ of remains found in feces collected on 4 August (Table 4). No simuliids were present and Trichoptera larvae were the most common prey item in feces collected on 3 July.

\section{Discussion}

Females spent $40 \%$ of daylight hours feeding during the prelaying period at Harlequin Brook, more than twice the time spent by males and higher than that reported in other studies. Prelaying females fed for $21 \%$ (including only time spent under water during dives) and $7 \%$ of daylight time in Alaska (Dzinbal and Jarvis 1984) and Iceland (Inglis et al. 1989), respectively. Excluding pause times during diving bouts, as in Dzinbal and Jarvis (1984), yields an estimate of $28 \%$ of daylight time spent feeding by prelaying females at Harlequin Brook. A high level of food availability was thought to account for low feeding rates in Iceland (Inglis et al. 1989). It also probably contributed to the lack of difference in the percentage of time spent feeding by males and females (Inglis et al. 1989), in contrast to the results of this study, the results obtained by Bengtson (1972) and Dzinbal and Jarvis (1984), and the differences typically observed in 
Fig. 2. Diurnal feeding patterns of Harlequin Ducks in the prelaying to early laying, incubation, and brood-rearing periods on Harlequin Brook, Hebron Fiord, Labrador, in 1996.
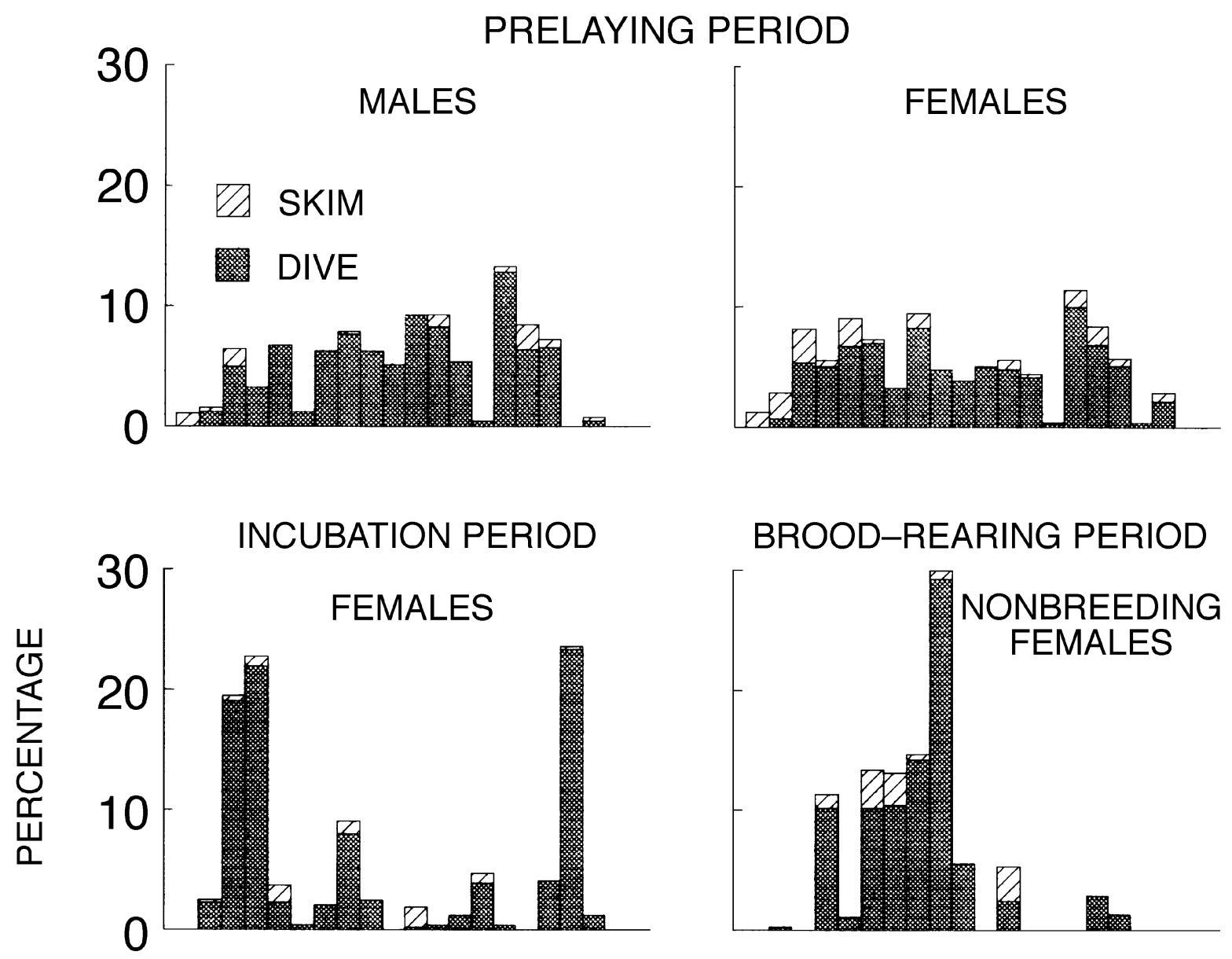

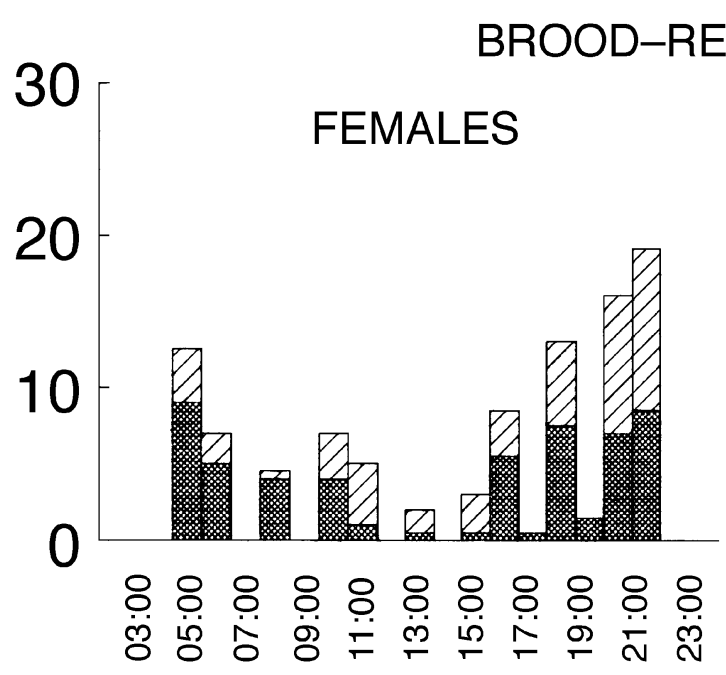

TIME 
Table 3. Comparison of dive and pause times and dive-pause ratios for paired males and females and unpaired females at Gooseneck Steadies on 19-21 June during the early laying period, females at Inukshuk on 15-18 July during the incubation period, and females at J-Kûk on 2-4 August during the brood-rearing period.

\begin{tabular}{llll}
\hline & Dive time (s) & Pause time (s) & Dive-pause ratio \\
\hline Gooseneck Steadies & & & \\
$\quad$ Paired males & $22.8 \pm 4.5(278)$ & $13.7 \pm 7.0(228)$ & $2.0 \pm 0.8(228)$ \\
$\quad$ Paired females & $21.5 \pm 5.9(233)$ & $11.9 \pm 5.8(181)$ & $2.2 \pm 1.0(181)$ \\
$\quad$ Unpaired females & $24.7 \pm 4.4(85)$ & $16.5 \pm 7.1(73)$ & $1.7 \pm 0.8(73)$ \\
Inukshuk & $10.0 \pm 4.3(104)$ & $7.6 \pm 5.3(83)$ & $2.2 \pm 1.9(61)$ \\
$\quad$ Females & $23.3 \pm 7.1(178)$ & $13.3 \pm 7.9(155)$ & $2.2 \pm 0.9(155)$ \\
J-Kûk & & & \\
$\quad$ Females & &
\end{tabular}

Note: Values are given as the mean \pm SD. Numbers in parentheses are sample sizes.

Table 4. Presence (+) and percent composition of prey remains in Harlequin Duck feces collected on 3 July (30 individuals identified) and 4 August 1996 (4493 individuals identified) at Harlequin Brook, Labrador.

\begin{tabular}{lcc}
\hline & 3 July & 4 August \\
\hline Simuliidae (Diptera) & 0 & 98.0 \\
Trichoptera & + & 0.7 \\
Plecoptera & + & 0.4 \\
Ephemeroptera & + & 0.1 \\
Coleoptera & 0 & 0.1 \\
Hydracarina (Acari) & 0 & $<0.1$ \\
Unknown & 0 & 0.7 \\
\hline
\end{tabular}

Note: Numbers of simuliid individuals were accurately determined by counting heads. Remains of other prey types were mostly leg parts, so numbers of individuals were more difficult to estimate.

ous studies. Observations revealed little variation during the prelaying period, as was found by Inglis et al. (1989) for the same period, and major peaks of activity in the morning and evening during incubation and brood rearing, similar to the overall summer patterns reported by Bengtson (1966, 1972) and Kuchel (1977). However, in contrast to Inglis et al. (1989), continuous feeding throughout daylight hours during the prelaying period could indicate low food availability at that time, resulting in the high proportion of time spent feeding by prelaying females. No evidence of nocturnal feeding was obtained, although sightings of flying and swimming birds at the estuary and J-Kûk indicated that some activity does occur in the predawn hours.

The extensive feeding in the slow-moving waters at Gooseneck Steadies was unexpected. Harlequin Ducks have rarely been sighted on lakes in Iceland (Bengtson 1966), and they mostly confine their feeding activity to swiftly running waters (Bengtson 1972; Kuchel 1977; Inglis et al. 1989). However, Kuchel (1977) reported frequent use of calm water and ponds during periods of high water and for brood rearing in Montana, and dense shrub cover was thought to attract Harlequin Ducks to a lake where a brood was successfully raised in Alaska (Dzinbal 1982). I suspect that Harlequin Ducks may have been nesting in the dense shrubs covering the islands in Gooseneck Steadies, where vegetation was similar to that of the islands where a nest was found above J-Kûk (Rodway et al. 1998). Trichoptera were abundant only at Gooseneck Steadies in June and may have been important in the diet at that time. In other habitats alternative foods may have been less available.

Fecal remains collected in August were composed primarily of simuliid larvae in a similar proportion to that reported in the diet for May to August in Iceland (Bengtson 1972). The fecal sample collected in early July differed most notably by the complete absence of simuliids. Simuliids also were not present in invertebrate samples taken in Harlequin Brook at the end of June, and were most abundant in August.

Diving was the predominant feeding behaviour for all classes of Harlequin Ducks, and for chicks formed a similar proportion of their feeding activity as skimming. In contrast, young chicks fed mostly by skimming in Iceland (Bengtson 1972) and rarely fed by diving until the age of 3-4 weeks in Montana (Kuchel 1977). Adult insects picked from the surface formed a large part of chicks' diet in Iceland (Bengtson 1972), and type of feeding behaviour probably relates to timing of insect emergence (Sedinger 1992). Much of the skimming behaviour recorded at Inukshuk was chicks scraping prey, possibly simuliid larvae or pupae, off shallow rocks. Adult black flies were also available at that time, as they emerged in large numbers for the first time in 1996 on 2-3 August (personal observation), coincident with the observations of brood-rearing behaviour. Greater handling time for adults (Sedinger 1992) may have made it advantageous for chicks to feed on the more concentrated larvae and pupae still attached to the substrate. At Gooseneck Steadies, chicks spent considerable time picking prey off the edge of the stream bank. Numerous Plecoptera were observed emerging along the stream edges at that time and may have been an important prey type. I have no information on the proportion of time spent feeding by harlequin chicks elsewhere, but the $45 \%$ I observed is similar to that reported for other diving species (Sedinger 1992).

The mean dive times of 22-24s at Gooseneck Steadies and J-Kûk were longer than the means of 16 and 20 s reported by Bengtson (1972) and Kuchel (1977). Shorter dive times in the 
shallower and faster water at Inukshuk were similar to those measured by Inglis et al. (1989). Maximum dive time was $35 \mathrm{~s}$ in this study and that of Bengtson (1972). Longer dives of 39 and $40 \mathrm{~s}$ duration have been recorded by Bengtson (1966) and Kuchel (1977), respectively.

Dive-pause ratios of 4.0 (Bengtson 1966; Kuchel 1977) indicated that Harlequin Ducks are the most efficient of sympatric diving ducks (Bengtson 1966, 1972). The lower ratios of 1.7-2.2 found in this study are similar to those reported for Oldsquaw (Clangula hyemalis), Red-breasted Merganser (Mergus serrator), and Barrow's Goldeneye (Bucephala islandica) in stream habitats in Iceland (Bengtson 1966). The similar dive-pause ratios at Gooseneck Steadies, Inukshuk, and J-Kûk imply that differences are not a function of habitat, water depth, or flow rate. There are no obvious methodological differences among studies, and reasons for the large discrepancy between my results and those of Bengtson (1966) and Kuchel (1977) are not apparent.

Low feeding rates for parents with broods and higher rates for birds without broods have been reported for other species (Afton and Paulus 1992). Kuchel (1977) reported that females rarely fed until their broods were several weeks old, but this seems unlikely, given the energy requirements of laying and incubation (Alisauskas and Ankney 1992). Alert behaviour by parent females was most common at Inukshuk and not recorded at Gooseneck Steadies, probably because of differences in habitat and feeding behaviour. At Inukshuk, where most feeding occurred towards the exposed center of the brook, the female often stood in alert posture on an exposed rock while her chicks were foraging. Most feeding by chicks at Gooseneck Steadies occurred close to shore while the female maintained a guarding position, swimming so as to keep her chicks between her and the shelter of the shrubcovered stream bank.

Streams used by Harlequin Ducks for breeding in boreal, subarctic, and montane areas have relatively low mean benthic animal standing crops and low productivity (Ulfstrand 1968; Bengtson and Ulfstrand 1971; Bengtson 1972). Low breeding density and a high frequency of nonbreeding, especially when productivity is reduced (Bengtson and Ulfstrand 1971), indicate that Harlequin Ducks are poorly buffered against variation in food supplies. Although feeding rates of prelaying Harlequin Ducks at Harlequin Brook were not high compared with those of some other waterfowl (cf. Krapu and Reinecke 1992), they were higher than those reported in other Harlequin Duck studies, and similar to or higher than those observed in other river ducks (Eldridge $1986 a, 1986 b$ ). This suggests that there may be greater energy constraints on foraging effort in river specialists than in dabbling ducks or other diving species. The higher prelaying feeding rate I observed in calm waters at Gooseneck Steadies than in faster waters in other studies provides some support for this idea.

\section{Acknowledgements}

This study was funded by the Canadian Wildlife Service, and by a Northern Studies Training Grant, and a grant from the Endangered Species Recovery Fund, of the World Wildlife Fund, awarded to W.A. Montevecchi. I thank John Gosse and Ian Fong for assistance with the field studies, as well as Jacko
Merkuratsuk from the Labrador Innuit Association, who helped establish the field camp. I am grateful to Bill Montevecchi, Bruce Turner, Scott Gilliland, John Gosse, and Ian Fong for help with study design. Major thanks go to Erin Williams for patiently sorting, identifying, and counting the thousands of insect parts from the fecal samples. Dave Larson and Murray Colbo helped with invertebrate sampling methods and identification, and Bernie Kelly drafted the map.

\section{References}

Afton, A.D., and Paulus, S.L. 1992. Incubation and brood care. In Ecology and management of breeding waterfowl. Edited by B.D.J. Batt, A.D. Afton, M.G. Anderson, C.D. Ankney, D.H. Johnson, J.A. Kadlec, and G.L. Krapu. University of Minnesota Press, Minneapolis. pp. 62-108.

Alisauskas, R.T., and Ankney, C.D. 1992. The cost of egg laying and its relationship to nutrient reserves in waterfowl. In Ecology and management of breeding waterfowl. Edited by B.D.J. Batt, A.D. Afton, M.G. Anderson, C.D. Ankney, D.H. Johnson, J.A. Kadlec, and G.L. Krapu. University of Minnesota Press, Minneapolis. pp. 30-61.

Altmann, J. 1974. Observational study of behavior: sampling methods. Behaviour, 49: 227-265.

Bengtson, S.-A. 1966. Field studies on the Harlequin Duck in Iceland. Wildfowl Trust Annu. Rep. 17: 79-94.

Bengtson, S.-A. 1972. Breeding ecology of the Harlequin Duck Histrionicus histrionicus (L.) in Iceland. Ornis Scand. 3: 25-43.

Bengtson, S.-A., and Ulfstrand, S. 1971. Food resources and breeding frequency of the harlequin duck Histrionicus histrionicus in Iceland. Oikos, 22: 235-239.

Cassirer, E.F., and Groves, C.R. 1991. Harlequin duck ecology in Idaho: 1987-1990. Natural Heritage Program, Idaho Department of Fish and Game, Boise.

Dzinbal, K.A. 1982. Ecology of Harlequin Ducks in Prince William Sound, Alaska during summer. M.Sc. thesis, Oregon State University, Corvallis.

Dzinbal, K.A., and Jarvis, R.L. 1984. Coastal feeding ecology of Harlequin Ducks in Prince William Sound, Alaska in summer. In Marine birds: their feeding ecology and commercial fisheries relationships. Edited by D.N. Nettleship, G.A. Sanger, and P.F. Springer. Spec. Publ., Canadian Wildlife Service, Ottawa, Ont. pp. 6-10.

Eldridge, J.L. 1986a. Observations on a pair of Torrent Ducks. Wildfowl, 37: 113-122.

Eldridge, J.L. 1986b. Territoriality in a river specialist: the Blue Duck. Wildfowl, 37: 123-135.

Goudie, R.I. 1991. Status report on the Harlequin Duck (eastern population) Histrionicus histrionicus. Can. Wildlife. Service (Atlantic Region) report prepared for the Committee on the Status of Endangered Wildlife in Canada, Ottawa.

Inglis, I.R., Lazarus, J., and Torrance, R. 1989. The pre-nesting behaviour and time budget of the harlequin duck (Histrionicus histrionicus). Wildfowl, 40: 55-73.

Krapu, G.L., and Reinecke, K.J. 1992. Foraging ecology and nutrition. In Ecology and management of breeding waterfowl. Edited by B.D.J. Batt, A.D. Afton, M.G. Anderson, C.D. Ankney, D.H. Johnson, J.A. Kadlec, and G.L. Krapu. University of Minnesota Press, Minneapolis. pp. 1-29.

Kuchel, C.R. 1977. Some aspects of the behavior and ecology of harlequin ducks breeding in Glacier National Park, Montana. M.Sc. thesis, University of Montana, Missoula.

Lehmkuhl, D.M. 1979. How to know the aquatic insects. Wm. C. Brown Co., Dubuque, Iowa.

Montevecchi, W.A, Bourget, A., Brazil, J., Goudie, R.I., Hutchinson, A.E., Johnson, B.C., Keho 1995. National recovery plan for the 
Harlequin Duck in eastern North America. Rep. No. 12, Recovery of Nationally Endangered Wildlife Committee, Ottawa.

Myers, M.T. 1959. The behaviour of the sea-ducks and its value in the systematics of the tribes Mergini and Somateriini, of the family Anatidae. Ph.D. thesis, University of British Columbia, Vancouver.

Pennak, R.W. 1953. Fresh-water invertebrates of the United States. Ronald Press Co., New York.

Rodway, M.S. 1998. Habitat use by Harlequin Ducks breeding in Hebron Fiord, Labrador. Can. J. Zool. 76: 897-901.

Rodway, M.S., Gosse, J.W., Jr., Fong, I., and Montevecchi, W.A. 1998. Discovery of a Harlequin Duck nest in eastern North America. Wilson Bull. 110: 282-285.
Sedinger, J.S. 1992. Ecology of prefledging waterfowl. In Ecology and management of breeding waterfowl. Edited by B.D.J. Batt, A.D. Afton, M.G. Anderson, C.D. Ankney, D.H. Johnson, J.A. Kadlec, and G.L. Krapu. University of Minnesota Press, Minneapolis. pp. 109-127.

Ulfstrand, S. 1968. Benthic animal communities in Lapland streams. Oikos Suppl. No. 10. pp. 1-20.

Wallen, R.L. 1987. Habitat utilization by harlequin ducks in Grand Teton National Park. M.Sc. thesis, Montana State University, Bozeman. 